\title{
The Impact of Oil Price Shocks on the Economic Growth of Selected MENA ${ }^{1}$ Countries
}

\author{
M. Hakan Berument ${ }^{*}$ Nildag Basak Ceylan ${ }^{* *}$ and Nukhet Dogan ${ }^{* * *}$
}

This paper examines how oil price shocks affect the output growth of selected MENA countries that are considered either net exporters or net importers of this commodity, but are too small to affect oil prices. That an individual country's economic performance does not affect world oil prices is imposed on the Vector Autoregressive setting as an identifying restriction. The estimates suggest that oil price increases have a statistically significant and positive effect on the outputs of Algeria, Iran, Iraq, Kuwait, Libya, Oman, Qatar, Syria, and the United Arab Emirates. However, oil price shocks do not appear to have a statistically significant effect on the outputs of Bahrain, Djibouti, Egypt, Israel, Jordan, Morocco, and Tunisia. When we further decompose positive oil shocks such as oil demand and oil supply for the latter set of countries, oil supply shocks are associated with lower output growth but the effect of oil demand shocks on output remain positive.

\section{INTRODUCTION}

Owing to its strategic nature, oil is an important commodity, affecting world economies. Fluctuations in world oil prices affect countries' current account balances and government revenue. In addition to their effect on aggregates, oil price developments are held responsible for domestic price movements and economic growth, as well as issues related to labor markets.

The Energy Journal, Vol. 31, No. 1. Copyright @2010 by the IAEE. All rights reserved.

* Corresponding author. Bilkent University, Department of Economics, 06800, Ankara, Turkey. e-mail: berument@bilkent.edu.tr.

** Atilim University, Department of Management, 06836 Kızılcaşar Köyü İncek, Ankara, Turkey. e-mail: nbceylan@ atilim.edu.tr.

*** Gazi University, Department of Ecnometrics, 06500 Besevler, Ankara, Turkey. e-mail: nukhed@ gazi.edu.tr.

The authors would like to thank Anita Akkas, Kamuran Malatyali, Rana Nelson and anonymous referees for their valuable suggestions and helpful comments.

1. MENA is the abbreviation of "Middle East and North Africa". 
Positive oil price shocks tend to affect the economies of oil-importing countries differently than oil-exporting countries. Oil price increases might be considered bad for oil-importing countries but good news for oil-exporting countries. The reverse might be expected for oil price decreases.

The immediate effect of positive oil price shocks is to increase the cost of production for oil-importing countries. This is likely to decrease output, and its magnitude depends on the shape of the aggregate demand curve. Higher oil prices lower disposable income and this decreases consumption. Once the oil price increases are perceived as permanent, private investments also decrease. Moreover, if the shocks are perceived as persistent, oil is used less in production, capital and labor productivity both decrease and potential output falls: the input cost effect. $^{2}$ Various studies, such as those of Rasche and Tatom (1977, 1981), Darby (1982), Burbidge and Harrison (1984), Hamilton (1983, 1996), Mork (1989), Santini (1985), Gisser and Goodwin (1986), and Lee et al. (1995) provide empirical evidence that rising oil prices reduce output and increase inflation. As a result, tax revenues fall and budget deficits increase. Oil price changes also affect trade and exchange rates. Oil consumption is difficult to decrease in the short run for oil-importing countries. When oil prices increase, the inelastic demand curve for oil means total spending on oil imports increases. This puts pressure on the exchange rate and depreciates the local currency. This depreciation, in turn, may further affect economic performance. Even if depreciation increases the aggregate demand for oil-importing countries, prices may increase due to the exchange rate pass-through and lower output may occur due to higher input costs (see Kamin and Rogers, 2000, for elaboration on this issue).

Oil production usually accounts for a large share of the GDP of oil-exporting countries and oil price increases directly increase the country's currency value (total oil production increases because the value of oil production increases: the income effect). However, the total effect of oil price shocks on economic performance mostly depends on what the oil producers (mostly governments) do with this additional revenue. Husain, Tazhibayeva and Ter-Martirosyan (2008) argue that oil prices affect economic performance through fiscal policy. Secondly, high oil prices increase real national income through higher export earnings, and create the terms-of-trade effect (see Kornonen et al., 2007). As a result, wealth will be transferred from oil-importing countries to oil-exporting countries, leading to greater purchasing power for economic agents of oil-exporting countries. Thirdly, even if appreciation of currency hurts the competitiveness of non-energy sectors, appreciated local currency that stems from higher oil revenues may stimulate investment and provide lower-priced imported intermediary products, which may stimulate production. Lastly, higher oil prices will also likely increase the profitability of the energy sector. This provides an opportunity for the in-

2. However, some authors, such as Okun (1975), Perry (1977), and Nordhaus (1980) argue that the cost-push effect of oil price shocks is limited because the economy-wide cost share of energy and the short-term elasticities of substituting between energy and other inputs are both quite small. However, Berument and Tasci (2002) notes that this effect will also depend on the degree of wage indexation. 
vestment and business sectors, with increased demand for labor and capital (see Bjørland, 2008).

Systematic oil price studies can be traced back to the middle of the 1970s, when an abrupt rise in oil prices due to the OPEC (Organization of Petroleum Exporting Countries) oil embargo was followed by a global recession. In fact, there is considerable literature, especially for relatively developed countries, that assesses the effects of oil price hikes on economic activity and the channels through which they are transmitted. The empirical findings of the pioneering researchers of the US market, Rasche and Tatom (1977, 1981), Darby (1982), Hamilton (1983), Burbidge and Harrison (1984), Santini (1985), and Gisser and Goodwin (1986) report a clear negative correlation between oil prices and real output.

The studies pertaining to non-US economies differ to a certain extent. For instance, Papapetrou (2001), examining the case of Greece using a Vector Autoregressive (VAR) model, reports a negative effect of real oil price changes on industrial production and employment. Similarly, Miguel, Manzano, and MartinMoreno (2003) study the case of Spain. They report a negative effect of oil prices on the country's welfare. However, Cuñado and Pérez de Gracia (2003), who study 15 European countries, obtain different results depending on whether they used a world oil price index or a national real price of oil index. Moreover, they are unable to find any co-integrating long-run relationships between oil prices and economic activity except for Ireland and the United Kingdom. Therefore, they suggest that the impact of oil shocks on economic activity is limited to the shortrun. Levin and Loungani (1996) also report significant differences in the gross domestic product (GDP) response to oil price shocks for G7 countries.

The effects of oil prices shocks on oil-exporting countries such as Canada, Denmark, Norway, and the UK are examined in some studies, such as those by Cuñado and Pérez de Gracia (2003), Jiménez-Rodríguez and Sánchez (2005), and Mork, Olsen, and Mysen (1994). Cuñado and Pérez de Gracia (2003) analyze the impact of oil prices on industrial production for a set of countries, including oilexporting Denmark and the UK. They report that even if the correlation coefficient between output growth and oil price changes is positive for Denmark, and it is negative for the UK. The impulse responses suggest that oil price shocks negatively affect Danish industrial production but positively affect the UK production. Jiménez-Rodríguez and Sánchez (2005) examine its effect on real economic activity for Norway and the UK and report that oil price shocks adversely affect UK output but favorably affect the Norwegian output. Similar to Jiménez-Rodríguez and Sánchez (2005), Mork, Olsen, and Mysen (1994) examine the correlations between oilprice movements and GDP fluctuations. The correlation estimates show a general pattern of negative correlation between GDP growth and real oil price increases for Canada and the UK but the estimated correlation is positive for Norway.

In addition to those studies of developed economies, some are performed on Saudi Arabia - a lesser-developed economy but a major oil-exporting country. In one of these studies, it is estimated that each one-US dollar oil price drop causes the Saudi economy to lose 2.5 billion US dollars of revenue annually (Brown and 
Yucel, 2000). Another study indicates that Saudi oil policy influences world inflation, which in turn contributes to Saudi inflation due to its imports (Aleisa and Dibooglu, 2002). This latter study finds that oil production shocks in the Saudi economy have a sizable effect on output through real exchange rate movements.

Oil prices had their fourth rally in last three decades between 1999 and 2008. Further research is needed on the effects of oil price movements, especially pertaining to developing countries. Such a study would not only fill the gap in oil macroeconomics literature but would also serve the needs of policy makers. As summarized above, the literature on oil is dominated by studies aiming to explore oil price changes, GDP growth, or the mechanisms which affect the economy of the United States. A proportionally fewer number of studies in the relevant literature, such as Bohi (1989), Levin and Loungani (1996), Cuñado and Pérez de Gracia (2003), Jiménez-Rodríguez and Sánchez (2005), and Mork, Olsen, and Mysen (1994) deal with other developed countries, especially those in the Organization for Economic Co-operation and Development (OECD). Even if the majority of these countries are oil importing, for the purposes of the studies, Canada, Denmark, Norway, and the UK were considered as oil exporting. Finally, a limited number of studies regarding this issue have been done on an oil-producing, nonOECD economy - Saudi Arabia. In a setting where oil prices are on the rise and relevant studies about oil price effects on individual economies are limited, there is an urgent need to close the gap.

This paper assesses the effect of oil price increases on a set of Middle East and North African (MENA) countries. Studying this set of countries has various advantages. Firstly, MENA countries consist of developing, less-developed, and least-developed countries and this study will fill the gap in the lack of evidence from these types of countries. Secondly, the region includes both oil-exporting and oil-importing developing economies. In such a structure, some of the economies in the region benefit from the windfall profits and fiscal revenues created by the oil price hikes, while others (being net importers of oil) experience this situation as an additional burden on their economies. The opposite effect would be expected if a decrease in oil prices occurs.

In order to assess the effect of oil price increases on a set of Middle East and North African countries, we used the following proposition: that the countries considered are too small to affect oil prices with their economic performance but their economic performance will be affected by oil prices. This proposition will be used as an identifying restriction within a dynamic framework to analyze how oil prices will affect the prospective countries' economic performances. In the current study, the exogeneity of world oil prices is assumed within a VAR framework with block exogeneity. In the model, oil prices affect the MENA countries' economic performances but not vice versa. In order to capture the dynamics of world oil price shocks on these domestic economies, a four-variable VAR, composed of oil price, real exchange rate, inflation, and output growth is employed, as done in Kamin and Rogers (2000) and Berument and Pasaogullari (2003). Moreover, for a set of oil-importing countries, following Uhlig (2005) and Lippi and Nobili (2008), we 
decompose oil price shocks as oil demand and oil supply shocks, and assess the effects of oil supply shocks on the economic performances of these countries.

With this motivation, this study aims to take a humble step towards filling the abovementioned gap in the field of oil macroeconomics as related to the MENA economies. This paper consists of five sections. The following section conveys the data sources, lists the selected MENA countries, and contains a brief overview of their economies. Section 3 lays out the econometric methodology that is used in this study, while Section 4 reports and discusses the empirical evidence gathered from the analyses. Finally, Section 5 summarizes and concludes the study.

\section{DATA AND THE SELECTED MENA ECONOMIES}

As indicated in the preceding section, the MENA region is a unique laboratory for the subject matter of this study as some of its constituent economies rely on oil export revenues, some are able to supplement their economies with limited domestic production, and others depend heavily on oil imports to meet their energy needs. These economies are interconnected through their labor markets and international trade linkages. However, since the aim of this study is to contribute to the oil macroeconomics literature in such a way as to emphasize the situation of the MENA economies with oil price taking behaviors, the economies to be studied are selected accordingly. Based on this rationale, this study elaborates on 16 countries of the region: Algeria, Bahrain, Djibouti, Egypt, Iran, Iraq, Israel, Jordan, Kuwait, Libya, Morocco, Oman, Qatar, Syria, Tunisia, and the United Arab Emirates (UAE). Table 1 provides the data time spans used in the paper for each country. The data used in the study are annual. The real GDP figures used in the econometric analysis range from 1952 to 2005, and within this time frame each country's specific period of analysis is determined by the availability of data. The GDP data are obtained either from the International Monetary FundInternational Financial Statistics (IFS) or World Development Indicators (WDI) databases, depending on the availability. For Algeria, Egypt, Iran, Iraq, Kuwait, Libya, Morocco, Qatar, and Oman, the nominal GDP values are obtained from IFS and deflated by the consumer price index data taken from IFS to calculate their real values. For Bahrain, Djibouti, Tunisia, and the UAE, the nominal GDP series is deflated by the GDP deflator, and both series are taken from WDI database. For Jordan and Syria, the GDP series is deflated by the GDP deflators taken from the IFS databases. For Israel, the nominal GDP series is obtained from WDI and deflated by the Consumer Price Index (CPI) gathered from IFS. The exchange rate and world oil price data are also obtained from the IFS, where the world oil price corresponds to the Dubai Spot Price Index. The Dubai petroleum is medium Fateh $32^{\circ}$ API, spot, f.o.b. gathered from Petroleum Market Intelligence, New York, International Crude Oil and Product Prices, Beirut, and Bloomberg Business News. Before 1984, the index was Middle East Light $34^{\circ}$ API, spot-obtained from Petroleum Intelligence Weekly, New York; and before 1974, it was Saudi Arabian Light $34^{\circ}$ API, posted price, ex Ras Tanura taken from Platt's Oil Price 
Handbook and Almanac, New York. The code of this index in IFS is 46676aaz.

Table 1. Time Span Used for the Analyses

\begin{tabular}{llll}
\hline Countries & Time span & Countries & Time span \\
\hline Algeria & $1969-2003$ & Kuwait & $1972-2004$ \\
Bahrain & $1980-2004$ & Libya & $1964-2004$ \\
Djibouti & $1987-2004$ & Morocco & $1952-2005$ \\
Egypt & $1952-2005$ & Oman & $1965-2003$ \\
Iran & $1959-2004$ & Qatar & $1979-2004$ \\
Iraq & $1953-1978$ & Syria & $1963-2002$ \\
Israel & $1983-2004$ & Tunisia & $1965-2004$ \\
Jordan & $1976-2003$ & UAE & $1973-2004$ \\
\hline
\end{tabular}

In order to observe the role of oil in the selected MENA economies, we calculated a set of statistics on oil. Table 2 lists the abbreviations of each variable that we use in this study. Table 3 reports the sample averages of OE/OP (ratio of Oil Exports to Crude Oil Production) for the time period between 1992 and 2004, and NOI/GDP (ratio of Net Oil Imports to the GDP) for the time period between 1971 and 2000, along with their variances and their maximum and minimum values. When these two ratios are examined closely, some countries appear as oilexporting countries even if they are not generally considered to be oil exporting; for example, Egypt, Syria, and Tunisia. These countries provide a supply of crude oil domestically and even export a portion of it. This picture is confirmed by the relevant NOI/GDP figure. Moreover, Bahrain appears as a relatively small and net oil-exporting economy. This result could be attributed to its relatively low NOI/GDP ratio, which is just above that of Egypt. ${ }^{3}$ Lastly, while NOI/GDP maximum and minimum values for Algeria, Bahrain, Egypt, Iran, Iraq, Kuwait, Libya, Oman, Qatar, and the UAE are always negative, for Israel, Jordan, and Morocco they are always positive. Thus, for the sample which we consider, this suggests that the former set of countries is always net oil-exporting, whereas the latter set of countries is always net oil-importing. Their extreme values indicate that there is no change in the oil exporting/importing status of the sample countries.

\section{Table 2. Definitions of Variables}

\begin{tabular}{ll}
\hline Variable & Definition \\
\hline GDP & Gross Domestic Product \\
CPI & Consumer Price Index \\
OE/OP & Ratio of Oil Exports to Crude Oil Production \\
NOI/GDP & Ratio of Net Oil Imports to the GDP \\
oil $_{t}$ & Oil Price \\
rer $_{t}$ & Real Exchange Rate \\
inf $_{t}$ & Inflation \\
growth $_{t}$ & Output Growth \\
\hline
\end{tabular}

3. Bahrain depends on Saudi Arabia for oil granted as aid (see World Fact Book, 2007). 
Table 3. Basic Magnitudes of the Sample Averages of the Countries of Interest

\begin{tabular}{|c|c|c|c|c|c|c|c|c|}
\hline & \multicolumn{4}{|c|}{ OE/OP } & \multicolumn{4}{|c|}{ NOI/GDP } \\
\hline & Mean & Min. & Max. & Var. & Mean & Min. & $\operatorname{Max}$ & Var. \\
\hline Algeria & 57.02 & 53.66 & 66.24 & 12.96 & -1.38 & -2.38 & -1.16 & 0.14 \\
\hline Bahrain & 4.22 & 0.00 & 9.91 & 21.94 & -0.47 & -1.64 & -0.16 & 0.15 \\
\hline Djibouti & --- & --- & --- & --- & --- & --- & --- & --- \\
\hline Egypt & 22.44 & 2.88 & 43.8 & 256.27 & -0.33 & -0.58 & -0.07 & 0.03 \\
\hline Iran & 65.59 & 58.08 & 72.73 & 28.95 & -1.85 & -4.91 & -0.78 & 1.36 \\
\hline Iraq & 43.86 & 11.3 & 80.71 & 1098.21 & -0.53 & -1.43 & -0.04 & 0.20 \\
\hline Israel & 0.00 & 0.00 & 0.00 & 0.00 & 0.13 & 0.01 & 0.19 & 0.002 \\
\hline Jordan & 0.00 & 0.00 & 0.00 & 0.00 & 0.58 & 0.32 & 0.73 & 0.011 \\
\hline Kuwait & 62.39 & 50.26 & 83.24 & 110.13 & -3.51 & -5.96 & -0.70 & 1.34 \\
\hline Libya & 76.40 & 72.21 & 81.82 & 10.34 & -1.90 & -2.91 & -1.25 & 0.18 \\
\hline Morocco & 0.00 & 0.00 & 0.00 & 0.00 & 0.17 & 0.15 & 0.20 & 0.00 \\
\hline Oman & 92.60 & 91.49 & 93.85 & 0.76 & -3.84 & -6.34 & -3.27 & 0.76 \\
\hline Qatar & 85.98 & 81.27 & 92.08 & 18.04 & -2.95 & -4.62 & -2.23 & 0.61 \\
\hline Syria & 56.27 & 48.50 & 60.45 & 15.09 & -1.21 & -1.70 & -0.02 & 0.22 \\
\hline Tunisia & 75.50 & 66.70 & 82.24 & 26.99 & -0.13 & -0.46 & 0.00 & 0.02 \\
\hline UAE & 83.30 & 76.05 & 89.74 & 25.02 & -2.66 & -7.03 & -1.89 & 1.68 \\
\hline
\end{tabular}

Source: Energy Balances of Non-OECD Countries 1993-1994, 1995-1996, 1996-1997, 1997-1998, 1998-1999, 1999-2000, www.iea.org.

The OE/OP values are average values from 1992-2004.

The NOI/GDP values are average values from 1971-2000.

\subsection{Developments in Oil Prices and Incomes}

Figures 1 to 4 show the composition of the various groups for which we plot an individual country's logarithm of the real GDP and the logarithm of real world oil prices, where each series is normalized at 1980 (or its closest year) to be equal to one. The first and the second groups consist of the Middle East countries that export and import oil, respectively. The third and the fourth groups are comprised of the North African countries that export and import oil, respectively. We calculate the real world oil prices by deflating the US dollar value of the oil price index with the US All Urban Consumer Price Index. The countries are divided into four categories here. The first group of countries consists of Bahrain, Iran, Iraq, Kuwait, Oman, Qatar, and the UAE. In the second group, we have Israel, Jordan, and Syria. Algeria and Libya are considered the third group; Djibouti, Egypt, Morocco, and Tunisia are considered the fourth group.

Figure 1 suggests that the GDPs of Qatar and the UAE move along with the oil price for the post-1980 period. The GDP of Kuwait moves almost oneto-one with the world oil price. With a few exceptions, the GDP of Iran can be considered to move with the oil price. The GDP of Iraq does not seem to move in line with the oil prices, which might be due to the lack of data. For the post-2000 
Figure 1. The Log Real GDPs of the Group I Countries

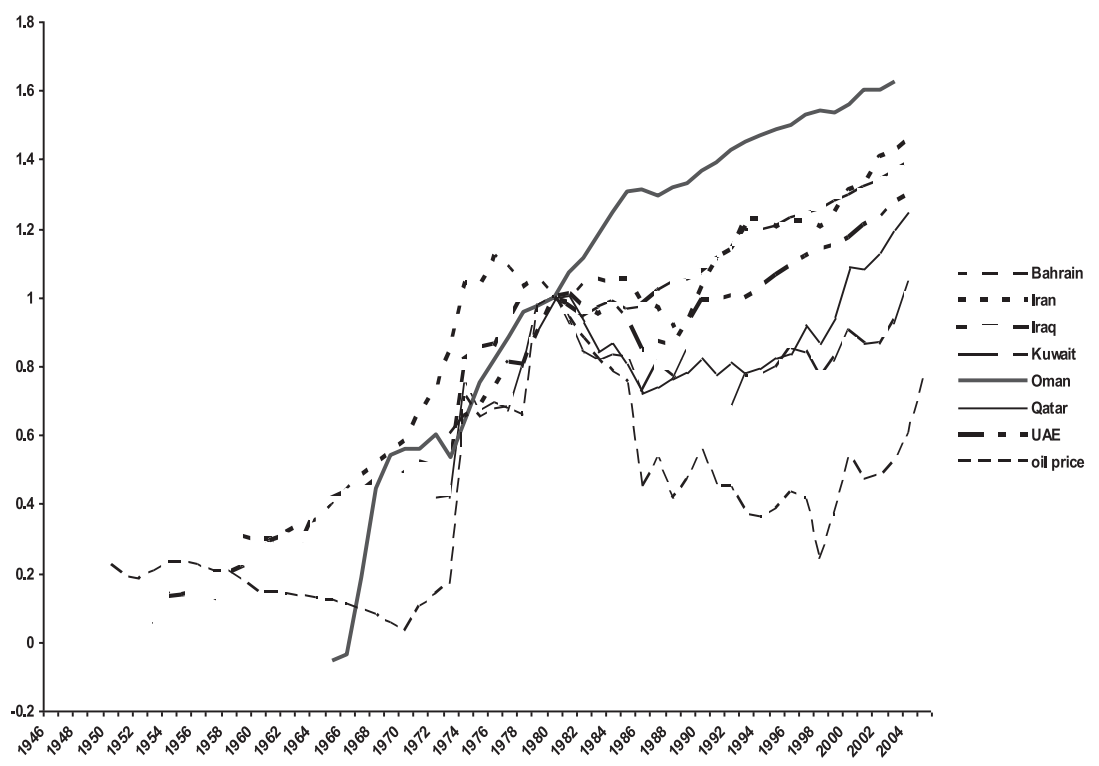

Figure 2. The Log Real GDPs of the Group II Countries

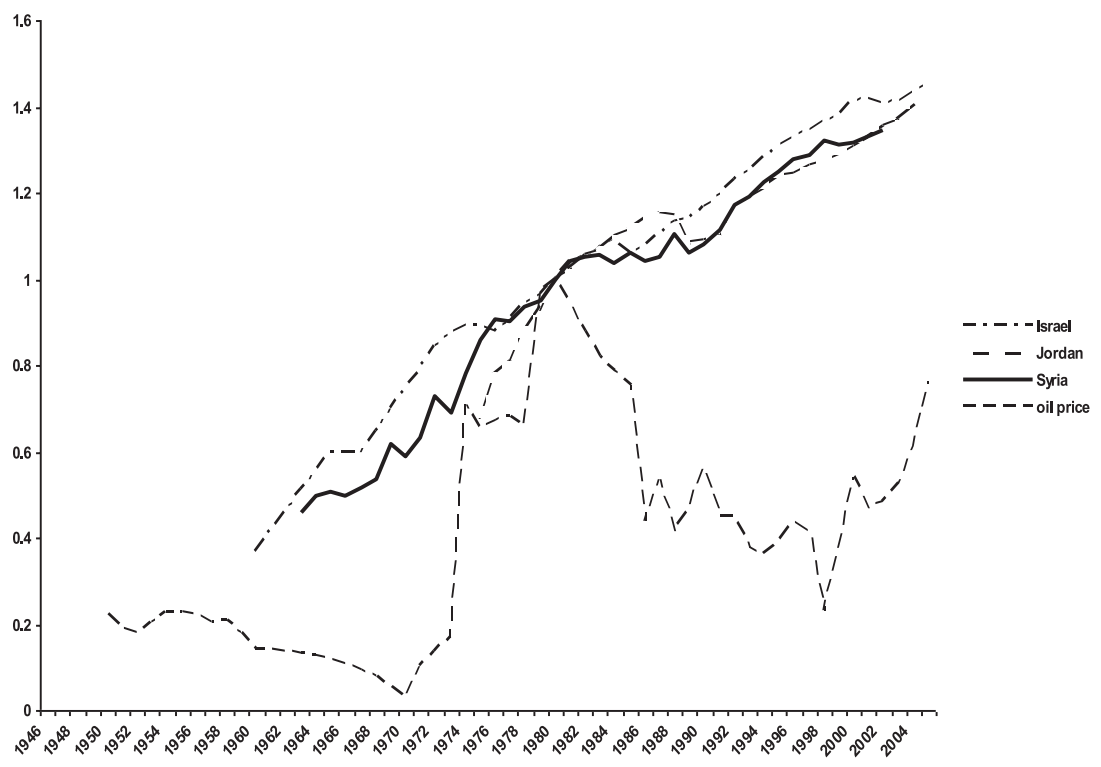




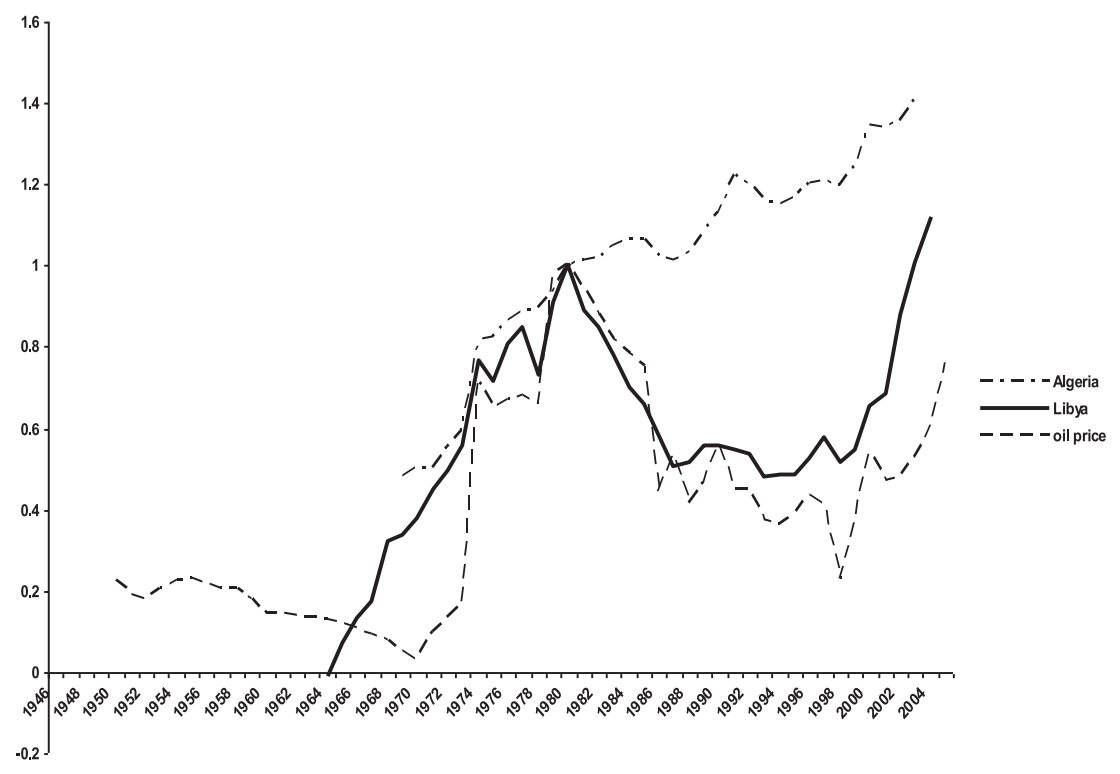

Figure 4. The Log Real GDPs of the Group IV Countries

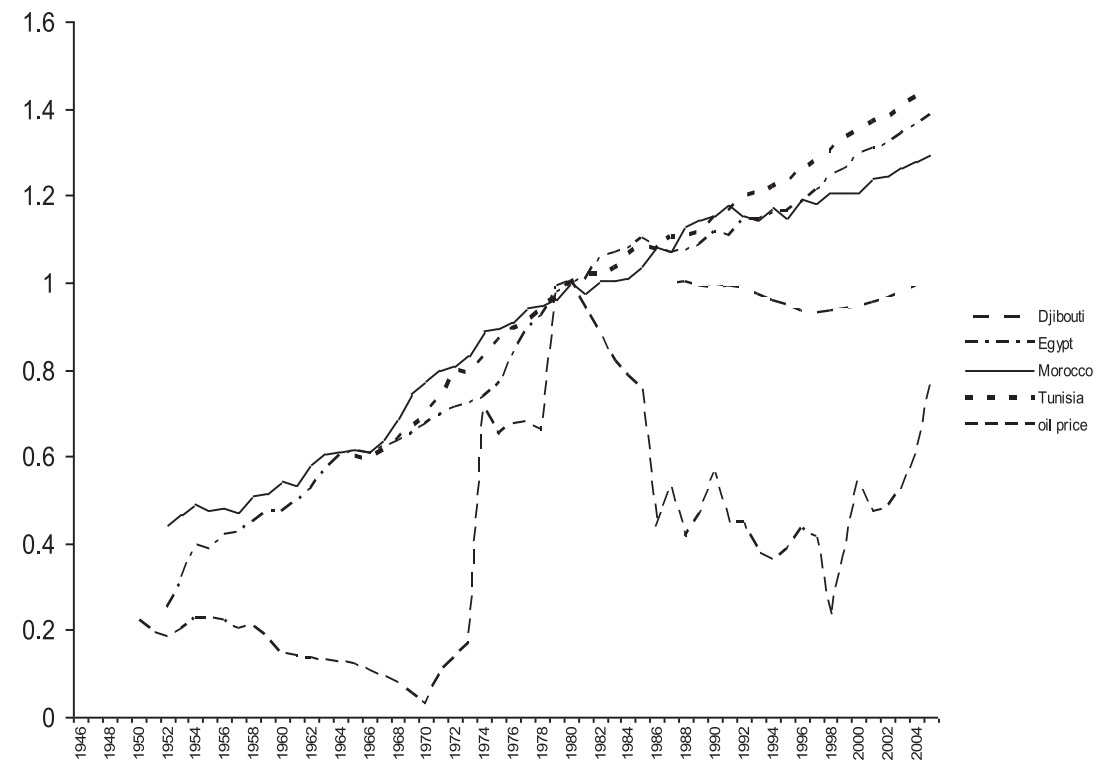


period, the GDPs of the countries increase as the oil price increases. Oman has an increasing GDP trend and it seems that the oil price drop in the 1980s did not affect its economic performance.

In Figure 2, the movements of the logarithm of real oil prices and the logarithm of the real GDPs of Israel, Jordan, and Syria are shown. The downward trend of oil prices between 1960 and 1970 is associated with higher Syrian output. The decreasing trend of oil prices in the 1980s and 1990s is associated with higher output for Israel, Jordan, and Syria but increasing oil prices decreased the growth rate of income for these countries.

Figure 3 shows movements in oil prices and the real GDPs of North African countries that export oil. With the exception of the 1960s, the GDP of Libya seems to move with the world oil price. Although the relationship between oil prices and the GDP is positive for Algeria for the 1970s and 2000s, this relationship is negative for the 1980s and 1990s.

Figure 4 indicates the movements of the oil prices and the logarithms of the real GDPs of Djibouti, Egypt, Morocco, and Tunisia. The GDPs of Egypt, Morocco, and Tunisia have an increasing trend starting from 1952 regardless of changes in oil prices. The data on Djibouti (available only after 1987) move with the oil prices.

\subsection{Relationships Between Oil Prices and GDPs}

In order to assess the relationship between world oil prices and individual countries' economic performances, two sets of analyses were performed as an initial step. Panel A of Table 4 reports the estimated coefficient of world oil real price growth when real GDP growth is regressed on a constant term and world oil real price growth. ${ }^{4}$ The estimated coefficients are positive for all 16 countries and statistically significant at the 5\% level for eight of them. The highest coefficients are for Kuwait, Iraq, Qatar, Libya, and Algeria. Even though these coefficients make sense for some oil-exporting countries, positive coefficients for oil-importing countries such as Djibouti, Israel, and Jordan are puzzling. Various reasons for these results might include the following: 1. The Ordinary Least Squares estimates cannot capture the effects of oil price changes on economies across time. Oil price shocks may affect output next year but not this year. 2. Output and oil prices may not capture the dynamics of the economy. We may need to observe the effects of oil prices on output after accounting for other factors such as the dynamics of output, inflation, real exchange rate, and even oil prices them-

4. When the logarithm of real oil prices and each real GDP series have a single unit root and if these series are cointegrated, then the OLS estimate between these two variables is admissible. For most of the countries, Table A1 of the Appendix indeed shows the presence of a unit root of these series but the cointegrations between the logarithm of the real oil prices and the logarithm of real GDP for each country are not present. Thus, we report the estimate in their first logarithmic differences in this subsection. 
selves. In order to account for the dynamic relationship, we calculated cross correlation between oil price growth rate and the growth rate of each country for five years; the estimates are reported in Panel B of Table 4. For the contemporaneous correlations, the coefficients are all positive. When we look at the cross correlation between current real oil price growth and the following year's GDP growth, the coefficients are negative for 10 countries, but none of them are statistically significant at the $10 \%$ level. An examination of the cross correlation across other periods reveals that they are mostly not statistically significant and a general pattern could not be detected.

Table 4. Relationships between Oil Prices and Economic Performance

\begin{tabular}{|c|c|c|c|c|c|c|c|c|}
\hline \multicolumn{2}{|c|}{$\begin{array}{c}\text { Panel A: } \\
\text { OLS }\end{array}$} & \multicolumn{6}{|c|}{$\begin{array}{c}\text { Panel B: } \\
\text { Cross Correlations }\end{array}$} & \multirow{2}{*}{$\begin{array}{c}\text { Panel C: } \\
\text { OLS } \\
\text { Contemp. } \\
\text { Imp. Resp. }\end{array}$} \\
\hline Country & & 0 & 1 & 2 & 3 & 4 & 5 & \\
\hline Algeria & $0.243^{* * *}$ & $0.817 *$ & -0.028 & 0.007 & -0.084 & -0.035 & 0.321 & $12.321 *$ \\
\hline Bahrain & 0.031 & 0.162 & 0.164 & 0.048 & 0.160 & 0.244 & -0.195 & 0.031 \\
\hline Djibouti & 0.004 & 0.071 & 0.237 & 0.277 & -0.048 & 0.005 & 0.066 & -0.033 \\
\hline Egypt & $0.047^{*}$ & 0.168 & -0.079 & 0.136 & 0.077 & -0.056 & -0.050 & 0.962 \\
\hline Iran & $0.221^{* * *} *$ & $0.583^{*}$ & 0.140 & 0.042 & 0.230 & -0.017 & 0.230 & $7.325^{*}$ \\
\hline Iraq & $0.450 * * *$ & $0.924 *$ & -0.081 & -0.139 & -0.004 & -0.091 & -0.091 & $18.379 *$ \\
\hline Israel & 0.007 & 0.097 & 0.180 & -0.217 & 0.053 & 0.057 & 0.009 & -0.376 \\
\hline Jordan & 0.038 & 0.266 & 0.172 & 0.009 & -0.003 & -0.110 & -0.175 & 1.736 \\
\hline Kuwait & $0.509 * * *$ & $0.901^{*}$ & -0.006 & -0.054 & 0.015 & -0.078 & 0.283 & $25.035^{*}$ \\
\hline Libya & $0.385^{* * *}$ & $0.616^{*}$ & -0.011 & 0.052 & 0.173 & 0.0006 & 0.177 & $14.790^{*}$ \\
\hline Morocco & 0.009 & 0.174 & 0.033 & 0.030 & 0.062 & 0.060 & $0.352^{*}$ & 0.970 \\
\hline Oman & 0.011 & 0.056 & -0.262 & -0.016 & -0.073 & 0.033 & 0.184 & -0.351 \\
\hline Qatar & $0.421 * * *$ & $0.758 *$ & -0.055 & 0.033 & 0.289 & 0.055 & 0.063 & $12.669 *$ \\
\hline Syria & 0.050 & 0.279 & -0.286 & $0.405^{*}$ & 0.039 & -0.057 & $0.386^{*}$ & 1.914 \\
\hline Tunisia & $0.039 * *$ & 0.271 & -0.259 & $0.425^{*}$ & $0.304^{*}$ & 0.127 & 0.088 & 0.825 \\
\hline UAE & $0.154 * * *$ & $0.445^{*}$ & -0.054 & 0.072 & 0.082 & -0.046 & 0.083 & $7.154^{*}$ \\
\hline
\end{tabular}

*** indicates the level of significance at $1 \%$.

$* *$ indicates the level of significance at $5 \%$.

* indicates the level of significance at $10 \%$.

Even if the cross correlations account for the dynamic effects of oil price increases on the real GDP, it does not control for other factors that affect domestic economic performance; this might be the reason for low test statistics for the cross correlation. In order to account for these, we will use a version of Kamin and Roger's (2000) VAR approach, but as an identification restriction, our model will introduce the proposition that world oil prices affect each country's economic performance but the economic performance of each country will not affect world oil prices. Therefore, our model uses a relatively large set of conditioning informa- 
tion that controls for the potential confounding of other factors such as inflation, real exchange rate, and the role of a country in affecting world oil prices. The next section elaborates on a model that incorporates these propositions. The estimates on Panel $\mathrm{C}$ will be elaborated on later in the text.

\section{METHODOLOGY}

In order to capture the dynamics of each country's economic performance, we adopt the three-variable VAR model of Kamin and Rogers (2000). The VAR model consists of each country's real exchange rate, inflation, and output growth. ${ }^{5}$ The MENA countries that we consider are small enough not to affect world oil prices. ${ }^{6}$ Thus, we used a similar Structural Vector Autoregressive (SVAR) model as suggested by Cushman and Zha (1997). In this structural (block recursive) model, we allow as an exogenous variable that oil prices affect the MENA countries' economic performance variables: real exchange rate, inflation, and output growth. However, we assume that these three domestic economic performance variables of each country cannot affect the world oil prices. Here, this four-variable VAR setup is different from the conventional four-variable VAR system in that none of the MENA countries' economic variables enter the oil price specification but the economic variables of the MENA countries are affected by the current and lag values of world oil prices.

The identified VAR model suggested by Cushman and Zha (1997) might be denoted as:

$$
A(L) y(t)=e(t)
$$

where $A(L)$ is an $m \times m$ matrix polynomial in the lag operator $\mathrm{L}, y(t)$ is the $m \mathrm{x} l$ observations vector, and $e(t)$ is the $m \times 1$ vector of structural disturbances. The specification of the model is as follows:

$$
y_{t}=\left[\begin{array}{l}
y_{1}(t) \\
y_{2}(t)
\end{array}\right], \quad A(L)=\left[\begin{array}{ll}
A_{11}(L) & A_{12}(L) \\
A_{21}(L) & A_{22}(L)
\end{array}\right], \quad \text { and } e_{t}=\left[\begin{array}{c}
e_{1}(t) \\
e_{2}(t)
\end{array}\right] .
$$

Here, $A(0)$ is non-singular and innovations $e(t)$ are assumed to be uncorrelated with $y(t-j)$ for $j>0$. The block $\left(y_{1}(t)\right)$ 's exogeneity is represented by $A_{12}(L)$ that is zero. It can be said that $y_{1}(t)$ is affected neither by $y_{2}(t)$ contemporaneously nor lag values of $y_{2}(t)$. On the other hand, $A_{21}(L)$ is not restricted to zero, so the

5. We could use more complete models to capture the dynamics of domestic economic performance, but lack of data and short data spans did not allow us to use a richer set of models.

6. In this paper, the 16 MENA countries mentioned in Section 2 are analyzed with regards to the effects of oil price shocks on their economies. As implied above, the Saudi Arabian case is excluded from the analysis as it is an oil-exporting country with the capacity of an oil price setter. Due to the unavailability of data, Lebanon, Palestine, and Yemen are also excluded. 
model specification allows oil prices to affect the domestic economy both contemporaneously as well as with lags. ${ }^{7}$

The observation matrices are $y_{1}=$ [World oil price], $y_{2}=[M E N A$ countries' real exchange rates, inflation, output growth]. For each MENA country, the lag order of the identified VAR model is 1, as suggested by the Bayesian Information Criteria.

In order to get orthogonalized residuals, we used the Cholesky decomposition in the second block $y_{2}$. The ordering of the variables is important. The first variable is the real exchange rate. This implies that the real exchange rate is affected by its own lags but not affected by the contemporaneous shocks of inflation and growth. The next variable, inflation, is assumed not to affect the real exchange rate but is assumed to be affected by the real exchange rate contemporaneously. Output growth is the third variable in the ordering which is considered to be affected by the other two variables contemporaneously, but not vice versa. In addition, the variables affect each other with lags. The order of the variables in the VAR model is similar to the studies of Kamin and Rogers (2000) and Berument and Pasaogullari (2003).

\section{EMPIRICAL EVIDENCE}

Using the SVAR model as introduced in the previous section, the impulse response functions of each MENA country are estimated by using annual data for the general period of 1952-2005. The real exchange rate is calculated as [(exchange rate $*$ USA CPI) / domestic price level], growth is the first difference of the logarithm of the real GDPs and inflation is the first difference of the logarithm of domestic price levels.

The impulse responses for the set of MENA countries are reported in Figure 5 . The impulse responses are obtained by giving a one-standard deviation shock (39.57) in the world oil price for the series of the real GDP growth of each country $^{8}$. In order to calculate the confidence interval bands, we adopt the Bayesian inference method of Zha (1999), with 2500 iterations. The confidence bands are reported at the $95 \%$ confidence levels. The middle lines in the figures represent the impulse responses. The confidence bands are reported as dotted lines. When the horizontal line falls into the confidence interval, then the null hypothesis that there is no effect of oil price shocks on output growth cannot be rejected. Thus, including the horizontal line for the particular time period obtained in this manner is interpreted as evidence of statistical insignificance.

7. Using conventional VAR specification with the Cholesky decomposition would allow shocks in the domestic economy that would not affect oil prices contemporaneously but would affect the world oil prices with lags. However, with block exogeneity, shocks to the domestic economy would affect world oil prices neither contemporaneously nor with lags. We believe that the lag values of economic indicators will not affect oil prices, which is a reasonable assumption. To save space, the above estimates are not reported here, however, they are available from the authors upon request.

8. See Enders (1995; 305-312) for impulse responses for VAR specifications. 
Figure 5. The Effects of One Standard Deviation Shocks to Oil Prices on Output

Figure a: Algeria

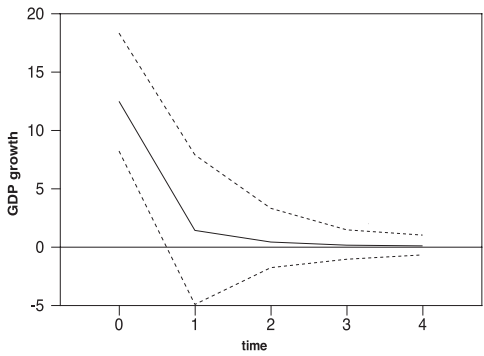

Figure c: Djibouti

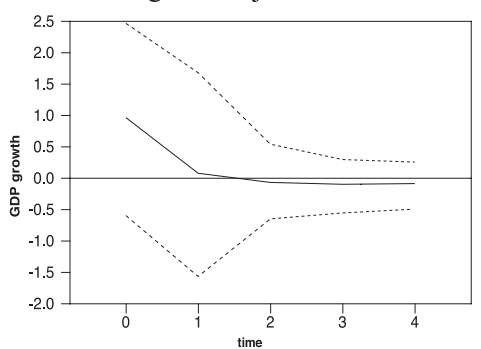

Figure e: Iran

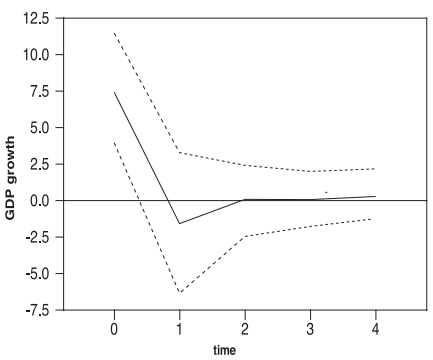

Figure g: Israel

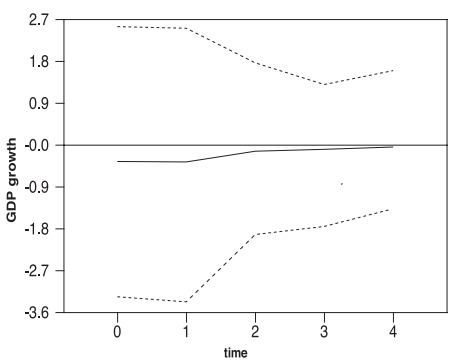

Figure b: Bahrain

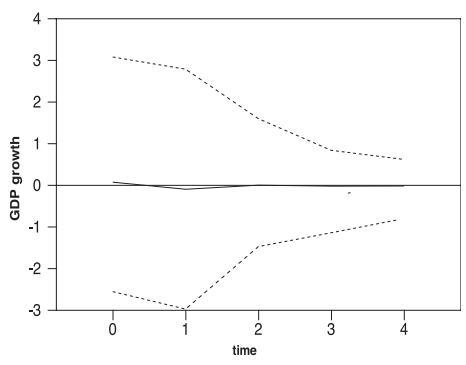

Figure d: Egypt

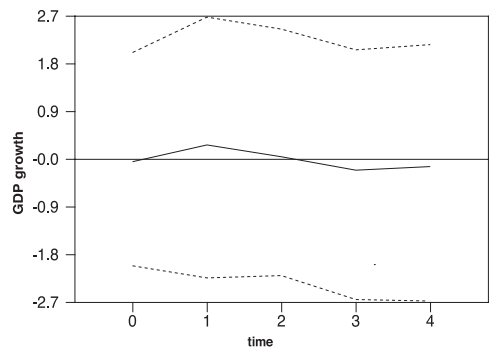

Figure f: Iraq

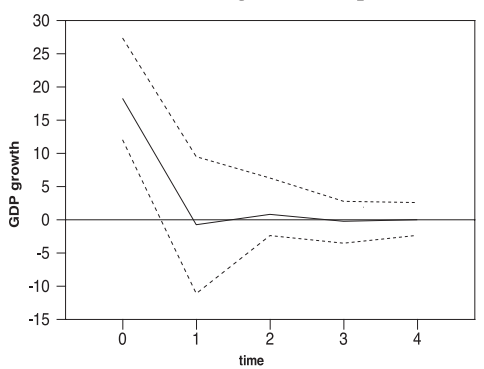

Figure h: Jordan

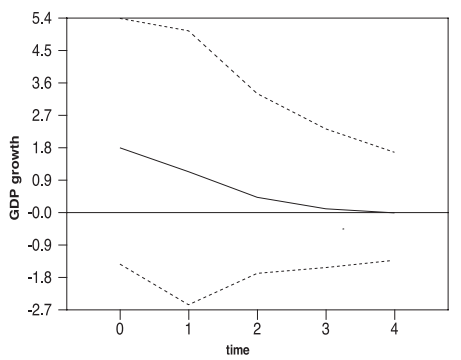


Figure 5. The Effects of One Standard Deviation Shocks to Oil Prices on Output (continued)

Figure i: Kuwait

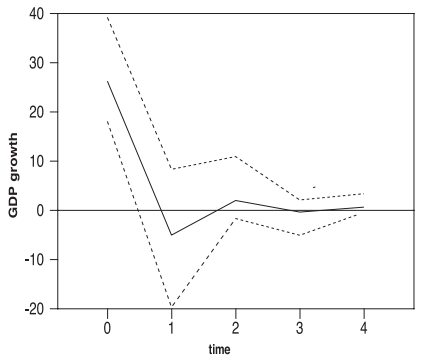

Figure k: Morocco

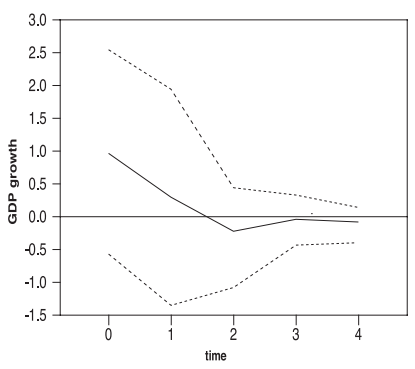

Figure m: Qatar

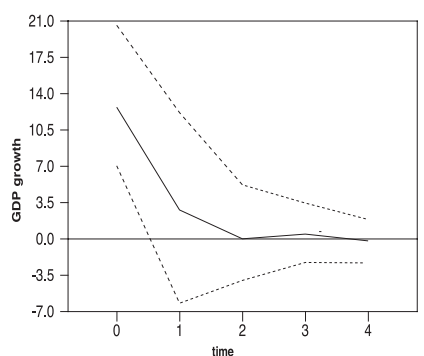

Figure o: Tunisia

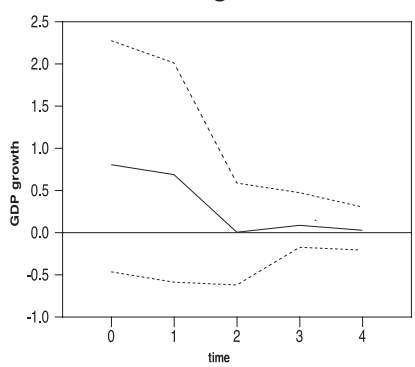

Figure j: Libya

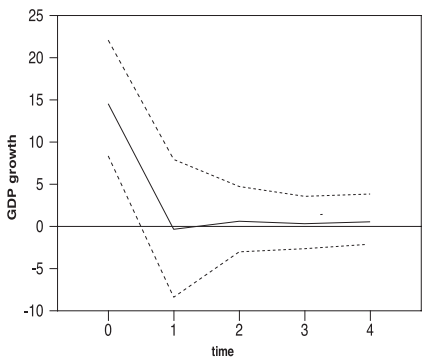

Figure 1: Oman

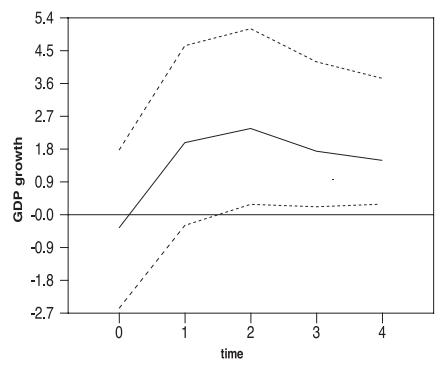

Figure n: Syria

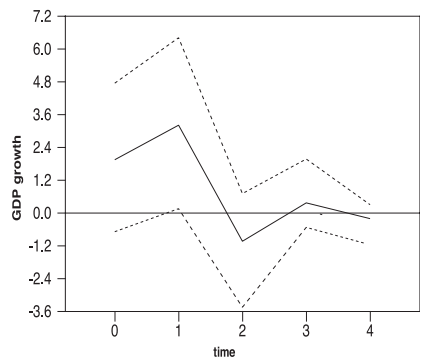

Figure p: UAE

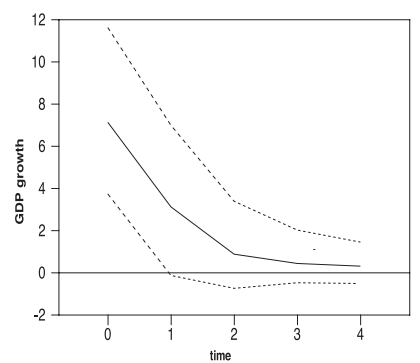


When the test results of each country are considered, it is observed that one standard deviation shock in oil prices has statistically significant, contemporaneous, and positive effects on the growth of the economies of Algeria, Iran, Iraq, Kuwait, Libya, Qatar, and the UAE. The significant and positive effects exist for the first period for Syria. Even though the contemporaneous effect is negative and insignificant for Oman, the positive effect of oil on growth after the second period persists. Observing that higher oil prices increase output for those oil-exporting countries is parallel to the expectations. As it is considered a net oil-exporting country, it is puzzling that estimates from Bahrain do not reveal positive and statistically significant effects on output. This result could be attributed to its relatively low scale of output with respect to its high crude oil imports (the oil-import over oil-production rate is 7.75 between 1996 and 2000), and its relatively low capacity to export (Bahrain's NOI/GDP ratio is just above that of Egypt). Bahrain is also dependent on Saudi Arabia for oil granted as aid (see World Fact Book, 2007). All these factors make it difficult to observe the oil price-income relationship for Bahrain.

On other economies -- Djibouti, Egypt, Israel, Jordan, Morocco, and Tunisia - the oil price shocks cause positive but not statistically significant effects on output. Note that these are mostly oil-importing or small oil-exporting countries. Evidence for Egypt and Tunisia may make sense as they are still marginally net oil-exporting countries, but evidence on others is puzzling. One may interpret this as evidence of the possible non-linearity of the relationship between oil prices and economic performance. This is something that we will elaborate on in the following sub-sections.

Panel $\mathrm{C}$ of Table 4 reports the contemporaneous impact on income for each country of one standard deviation shock to oil prices. It is clear that there is a strong relationship between oil dependence (Table 3) and contemporaneous effects; the correlation coefficient between the OE/OP and the contemporaneous effect is $40 \%$ and the correlation between NOI/GDP and the contemporaneous effect is $48 \%$. Of all the countries, Algeria, Iran, Iraq, Kuwait, Libya, Qatar, and the UAE, which are prominent oil producers, tend to be affected by oil price shocks mostly in the period when the shock occurs. When the OE/OP ratios are compared, on average, the countries that have a non-statistically significant effect on growth have lower ratios than the more-affected countries do. One country may export one type of oil (for example, low quality) and import another type of oil (e.g., high quality). Thus, next we look at NOI/GDP, which takes this into account. A similar strong association between contemporaneous impulse responses and the NOI/GDP ratios is also observed.

Our VAR analysis also includes real exchange rate and inflation. The empirical evidence provided from the benchmark specification suggests that currency appreciates in a statistically significant fashion for Oman and the UAE (not reported here to save space). Both of these countries are net oil exporting, with a relatively big oil sector in their respective economies. Currency appreciates for Iran, Kuwait, Syria, and Tunisia but these effects are not statistically significant. 
For the remaining countries, oil prices depreciate the currency but the effect is not statistically significant. One needs to be cautious about the exchange rate effects of oil price shocks because the effect may depend on the exchange rate regime, and the willingness of central banks to use their exchange reserves for a share of oil during international trade transactions. The existing empirical evidence on the effects of oil price increases on local currency is mixed for oil-importing countries, but local currency does appreciate with oil price increases for oil-importing countries ${ }^{9}$. Appreciation of the local currency, as argued by Kamin and Rogers (2000), may further stimulate an economy. One may elaborate on the role of the real exchange rate as a transmission mechanism for oil shocks on output and inflation, but we did not explore this issue in the current study.

\subsection{Non-Linear/Asymmetric Effects ${ }^{10}$}

Non-linearity or asymmetry for the relationship between oil prices and output could be a reason for finding the positive (but non-statistically significant) relationship between the two series for net oil importing and non-major-oil-exporting countries such as Djibouti, Egypt, Israel, Jordan, Morocco, Syria, and Tunisia.

The non-linearity between oil prices and output is explicitly elaborated on in the literature. As a way to address non-linearity, Cuñado and de Gracia (2003) analyze the effect of oil price changes by looking at the asymmetric effect of oil price changes on output for a set of European countries. Following the existing literature, they measure oil prices in four different ways. These four methods are: oil price growth from four quarters earlier; only the positive of these growths; maximum growth level of oil prices compared to one, two, three, and four years prior; and the positive standardized oil price shocks with the conditional standard deviation that comes from the GARCH $(1,1)$ specification. They provide the evidence that (i) oil price increases lower the output but the evidence for oil price decreases on output is not statistically significant and (ii) oil price shocks' effect on output is higher when oil prices are more stable than when they are more volatile. Their results suggest non-linear relationship(s) may exist between oil prices and output.

In a later study, Jiménez-Rodríguez and Sánchez (2005) extend the previous study by including Norway (a net oil-exporting European country) and a set of non-European countries including Canada, Japan, and the US. They also consider positive as well as negative standardized oil shocks to the analyses. They

9. For example, when oil prices increased, Amano and Van Norden (1995) found appreciation for Germany, Japan, and the US, however, Maeso-Fernandez et al. (2002), Jiménez-Rodríguez and Sánchez (2005) and Chen and Chen (2007) showed that a rise in real oil prices led to a depreciation of the real exchange rate for G7 countries. On the other hand, Golub (1983), Corden (1984) and De Grauwe (1996) reported the appreciation of the local currency for oil-exporting countries.

10. These estimates are not reported here in order to save space. These estimates and other estimates that are not reported in the manuscript are available at http://nukhetdog.googlepages.com/ supplement_01.pdf or from the authors upon request. 
find that the effect of oil-price rise on output decline is higher than the effect of oil-price fall on output increase. With the oil-exporting countries in their sample (Norway and the UK), oil price increases favorably affect Norway but adversely affect the UK.

In order to partially address the misspecification functional form, following Lee, Ni and Ratti (1995), Hamilton (1996), Cuñado and de Gracia (2003), and Jiménez-Rodríguez and Sánchez (2005), we consider a set of specification that allows non-linearity. We adopted classes of non-linear models such that the model specifications are the same across countries and thus comparison of the estimates are feasible. ${ }^{11}$ For the seven countries that we examine, in particular, positive and statistically significant evidence on Syria remains mostly robust. For Egypt and Tunisia, in the contemporaneous period and only when the standardized negative oil price shocks are considered, were the effects statistically significant. The evidence from these two countries was not statistically significant in our benchmark specification. For the estimates of the four remaining countries - Djibouti, Israel, Jordan, and Morocco - the evidence was not statistically significant for the four general classes of specification that we consider. Lastly, when they were statistically significant under the benchmark specification in our paper (all of them are net oil-exporting countries), compared to the nonlinear model specifications our estimates were robust.

\subsection{Robustness Analyses}

In this sub-section, in order to validate our specification, we will discuss a set of estimates that we perform for the robustness of our inferences. Firstly, a four-variable VAR setup might be too much to ask from the data as its time span is too short for some countries. Therefore, our model could be considered as over-parameterized. In order to account for this, we consider a two-variable set up: oil price growth and the individual country's growth. We assume that oil price growth follows its own dynamics as in our SVAR specification, and that the second variable, an individual country's growth, follows its own lags as well as oil price growth and the lag value of oil price growth. The countries that have positive and statistically significant contemporaneous effects of growth to oil price shocks (Algeria, Iran, Iraq, Kuwait, Libya, Qatar, and the UAE) in our benchmark specification are still positive and significant in the two-variable model. For the country that has a positive and significant effect (Syria) in the first period of the benchmark model, the result is still positive and significant in the first period. In the benchmark specification, the oil price shock was positive and significant after

11. We initially measure oil price changes as $\Delta$ oil $_{t}=\ln \left(\right.$ oilprice $\left._{t}\right)-\ln \left(\right.$ oilprice $\left._{t-1}\right)$ as in the benchmark specification. Later we consider positive and negative changes separately. Thus, we define $\Delta$ oil $_{t}^{+}$ $=\operatorname{Max}\left(0, \Delta o i l_{t}\right)$ and $\Delta o i l_{t}^{-}=\operatorname{Min}\left(0, \Delta o i l_{t}\right)$. As a third type of variable we consider $N O P I_{t}=\operatorname{Max}_{0}[0$, $\left.\ln o i l_{t}-\ln \left[\operatorname{Min}_{\left(\ln o i l_{t-1}\right.}, \ln \operatorname{sil}_{t-2}\right]\right]$. Lastly, we consider positive-only and negative-only standardized oil price shocks. To be particular, we estimate the following specification $\Delta$ oil $l_{t}=\alpha+\beta_{1} \Delta o i l_{t-1}+\varepsilon_{t}, \varepsilon_{t} N(0$, $\left.h_{t}^{2}\right) ; h_{t}^{2}=\gamma_{0}+\gamma_{1} \varepsilon_{t-1}^{2}+\gamma_{2} h_{t-1}^{2}$. The two variables that we define are $\operatorname{SOPI}=\operatorname{Max}\left(0, \hat{\varepsilon}_{t} / \hat{h}_{t}\right)$ and $S O P D_{t}=$ $\operatorname{Min}\left(0, \hat{\varepsilon}_{t} / \hat{h}_{t}\right)$. 
the first period for Oman, but the evidence is not significant when we perform the analysis with two variables. Among the estimates that are reported as statistically insignificant, the results on Israel, Jordan, Morocco, and Tunisia are robust but others change slightly.

One may also suggest that oil price shocks may not capture the real exogenous influence stemming from global macroeconomic developments. In order to account for this, as a second robustness specification we include the world GDP growth as an exogenous variable to the SVAR system. For the set of countries where contemporaneous positive and statistically significant effects are observed (Algeria, Iran, Iraq, Kuwait, Libya, Qatar, and the UAE), the results are robust. The effect of an oil shock on Omani output was statistically significant after the first period in our benchmark model, but when we include the world output growth, the effect is statistically significant only for the second period. Moreover, when we include the world output growth, the effect on the Syrian output is no longer statistically significant.

For the third specification, measuring real oil price by using world oil prices in US dollars and deflating by the US CPI may not capture the oil price's effect in a domestic economy. One may also convert the dollar price of oil into domestic currency with a local exchange rate and then deflate by the country's CPI. However, the second method would allow domestic shocks that affect the domestic exchange rate to also affect the real oil price measure of a country. This method cannot be considered an exogenous shock that stems from the oil prices to an economy. This problem can be practically solved by putting the exchange rate before the real oil prices and requiring conventional VAR model estimation rather than SVAR, as elaborated in the methodology section. Nevertheless, we estimate the specification, and while most of the results are robust with our estimates, the estimates from Kuwait and Djibouti cannot be gathered due to perfect multi-colinearity. Overall, the results from the benchmark SVARs were basically strong, and under the alternative specifications considered in this sub-section, the results are either robust or weaker.

The block-exogeneity assumption for Iran, Iraq, and Kuwait might be inappropriate. We estimated the model without block exogeneity as another robustness specification. The $p$-values of the growth in the oil specification as well as the growths in RER and inflation were higher than the conventional 5\% level for these three countries. Nevertheless, we estimated the impulse responses and the results were robust for all three countries. Bayesian Information Criteria suggested a lag length of one for the benchmark SVA specification. We tested the autocorrelation for each equation for each country if the residuals were uncorrelated. None of the Q-statistics are significant at the 5\% level for the growth equation. Therefore, we kept the lag order as one. However, when we looked at the autocorrelation for the other equations (Real Exchange Rate and Inflation), we observed some degree of autocorrelation for Bahrain, Egypt, Iraq, Morocco, and Tunisia. We performed the analysis with the extended lags as a fifth set of robustness specification, with the result that autocorrelation disappeared for these countries. The statistical evidence 
for the effect of oil prices on growth, similar to the benchmark model, was not statistically significant for Bahrain, Egypt, Morocco, or Tunisia. Moreover, similar to the benchmark specification, impulse responses for Iraq were positive and statistically significant contemporaneously only.

Most of the studies that assess the effect of oil prices on economic performance are for industrial countries and they use quarterly data. Quarterly data is also used as a last set of robustness specification to assess the relationship between oil prices and growth in two ways. In the first set of estimates, we were able to gather quarterly data only from Iran, Israel, and Jordan. In these countries, output seems to increase contemporaneously with oil prices. The result for Iran is parallel to the benchmark annual specification, and for Jordan, stronger. On the other hand, the estimates are not parallel to expectations that output decreases with oil price increases. In the second set, we used interpolated data for the remaining countries; the estimates had wide confidence bands and none of the estimates was statistically significant.

\subsection{Caveats}

Due to data availability, in order to calculate the real output data, nominal GDP figures are deflated by either the CPI or a GDP deflator. Bryan and Cecchetti (1993) and The Boskin Commission Report (1996) argue that the CPI overestimates true inflation. After the Boskin Commission report, the CPI was overhauled and the upward bias was corrected for the USA. However, Gordon and van Goethem (2005) argue that even after the overhaul, a significant upward as well as a downward bias remained. If there is an upward bias for the countries that we consider, then this makes the CPI-deflated real output lower compare to the GDP-deflated output, and the estimated parameter of real GDP will be higher. Thus, comparability of results across countries is difficult. For example, oil producers for whom inflation is measured by CPI are not as influenced by oil shocks as when measured by a GDP deflator. This makes it difficult to compare the impulse responses of the real output to the oil price disturbance, especially for oil producers. For the latter countries, taking the best measure of the real GDP deflated by a GDP deflator as a benchmark, deflating by CPI should yield an upward bias in the estimate of real output effects of oil shocks. Therefore, using both CPIs and GDP deflators as a deflator for different countries is a limiting factor in the comparability of results across countries.

\subsection{Estimates on Oil-Importing Countries}

It is important to recognize that the effects of oil price increases on output growth of individual countries are mostly positive. We do not find negative and statistically significant effects of oil price shocks on the output growth even for oil-importing countries. Not finding these effects of oil price increases on oilimporting countries does not contradict the existing literature. Bernanke et al. 
(1997, p. 94) write that "it is surprisingly difficult to find an indicator of oil price shocks that produces the expected responses of macroeconomic and policy variables in a VAR setting." Mountford (2005) found that positive oil shocks (even non-significant ones) increase output for two periods in the UK. Similarly, Hooker (1996) argues that after 1973, oil prices no longer Granger causes to output and Jiménez-Rodríguez and Sánchez (2005) observed that Japanese output increases with oil shocks. Jiménez-Rodriguez (2008) also argues that even if "[a]n oil price increase lowers the level of aggregate manufacturing output in all countries under study ... [t] his similarity of response is, however, unclear when we consider the eight industry groups within manufacturing." She observes that textile, wearing apparel, and leather industry output increases for France, Germany, and Spain with positive oil price shocks. However, this does not mean that adverse effects of oil price shocks for growth are not present.

Lippi and Nobili (2008) maintain that the source of oil shocks may affect economic performance differently; to be specific, oil price increases due to higher oil demand shocks affect output differently than oil price increases due to lower world oil supply shocks. They argued that positive oil supply shocks decrease domestic production. In order to assess the effects of oil supply shocks, we employ the sign-restrictions approach pioneered by Canova and Nicolo (2002) and Uhlig (2005). We set up a three-variable VAR model that includes world crude oil production, ${ }^{12}$ real price changes, and domestic growth rates. Following Lippi and Nobili (2008), we define positive oil supply price shocks such that oil production decreases but oil prices increase at the contemporaneous period where no additional restrictions are put on for additional periods as well as for their effect on output.

Figure 6 reports the response of output to oil supply shocks; following Dedola and Neri (2006) and Uhlig (2005), the median line and dashed lines are for the confidence intervals. Positive oil supply shocks decreases output for Egypt, Israel, Jordan, Morocco, Syria, and Tunisia. These effects are statistically significant for at least one year. Even if the contemporaneous effect is positive for Israel, this is not significant. The effect is negative and statistically significant in the second and third years. The only puzzling result is from Djibouti. Even if the effect is not statistically significant, it is positive. The answer may lie in the economic structure of the economy. Djibouti's largest source of economic and commercial activity is the French military base. The remainder of the economy is based on service activities and centered upon the free port of Djibouti. The country provides services as both a transit port for the region and an international shipment and refueling center. Djibouti has few natural resources and a small industry base. Therefore, the country heavily depends on foreign aid to finance development projects and support its balance of payments. Moreover, as there is little arable farmland, most food must be imported. The small industry base and little agriculture result in the adverse effect that oil supply shocks to the economy is small. In

12. The world crude oil production information is gathered from Energy Balances of Non-OECD Countries, from the OECD. The available data begins after 1983. 
Figure 6. The Effects of Oil Supply Shock on Output for Oil Importing Countries
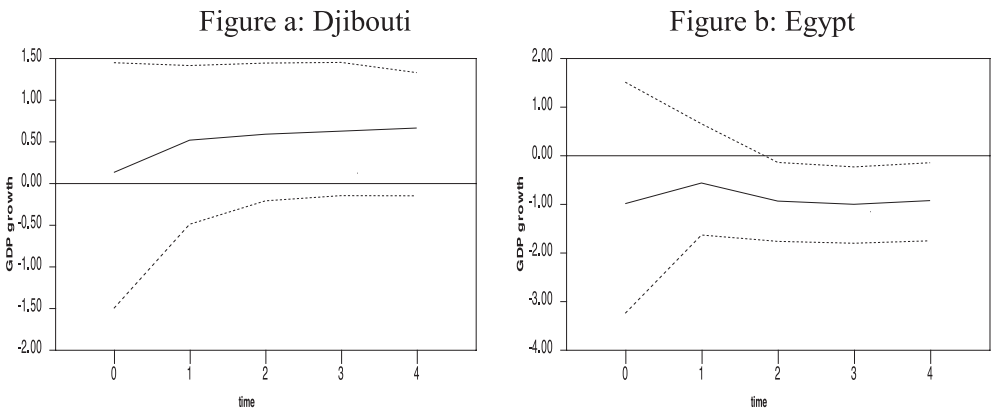

Figure c: Israel

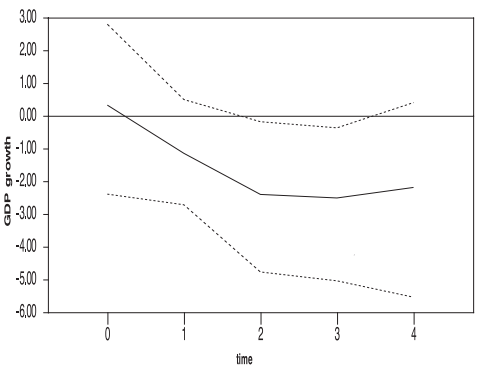

Figure d: Jordan

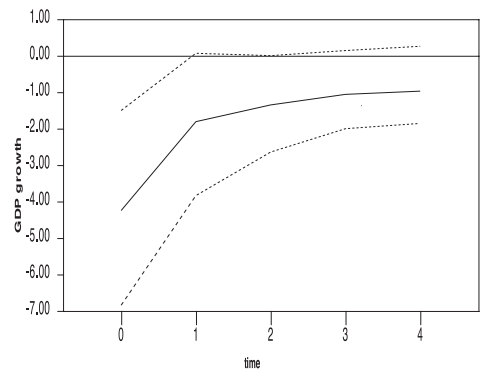

Figure e: Morocco

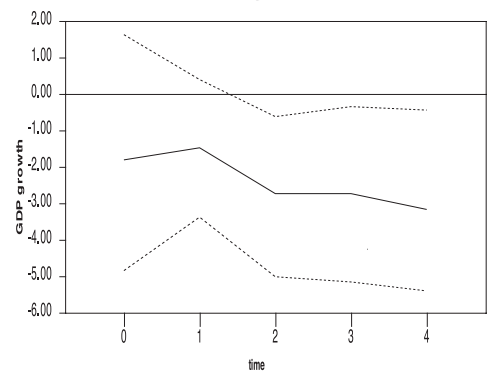

Figure f: Syria

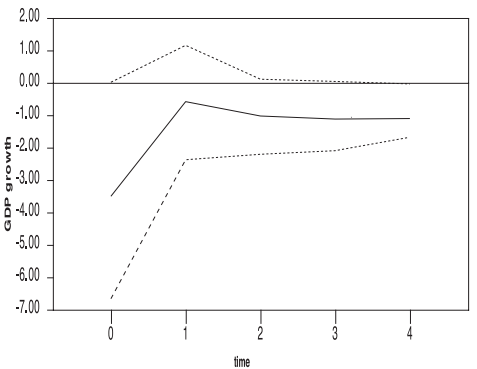

Figure g: Tunisia

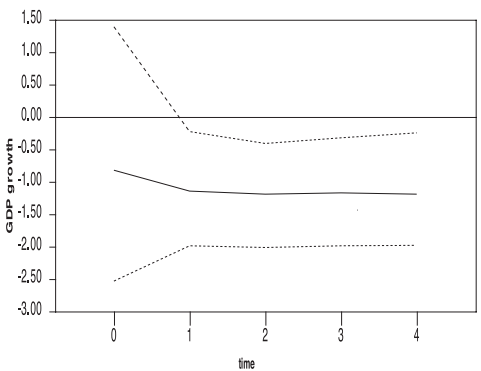


Figure 7. The Effects of Oil-Demand Shock on Output for Oil-Importing Countries

Figure a: Djibouti

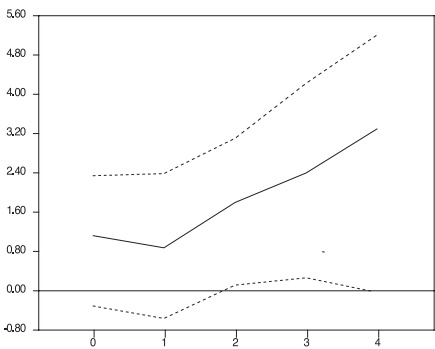

Figure c: Israel

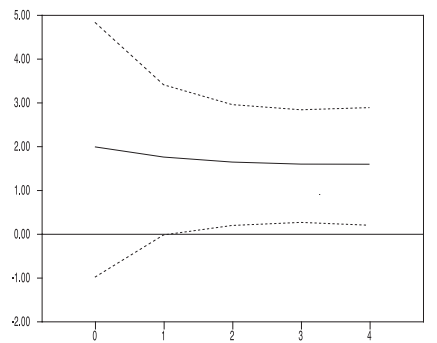

Figure e: Morocco

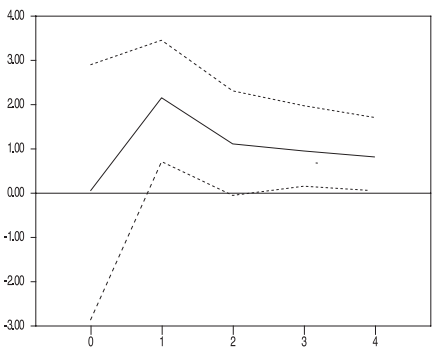

Figure g: Tunisia

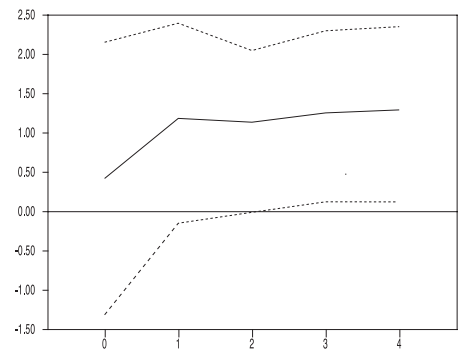

Figure b: Egypt

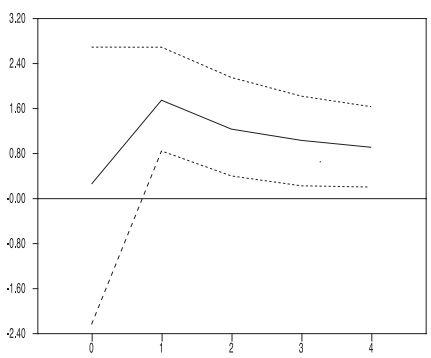

Figure d: Jordan

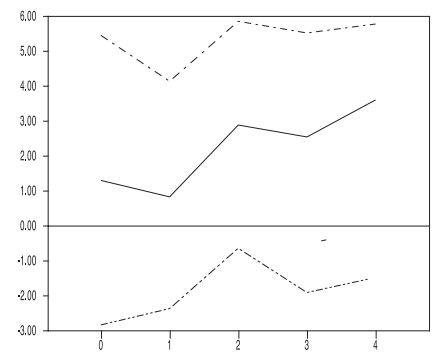

Figure f: Syria

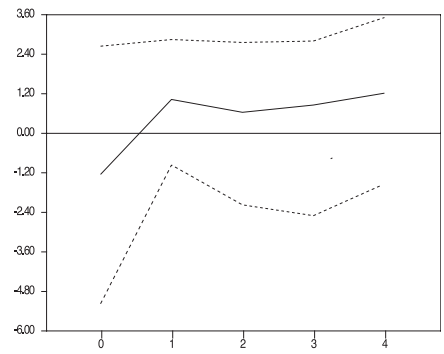


addition, the service revenue provided from transshipment may increase with oil prices. The above factors make the estimates from Djibouti realistic. Overall, we claim that positive oil supply shocks make sense with the economic priorities for these seven countries.

We repeat the above exercise of supply shocks for oil demand shocks. The estimates are reported in Figure 7. Oil demand shocks are defined as shocks that increase both world oil production and world oil prices. The effect of oil demand shocks for oil-importing countries are all positive except for Syria, and then only contemporaneously. These effects are statistically significant for all but Jordan and Syria, and mostly support the argument that oil demand, not oil supply shocks are the main reason for the increase (but not significant) in output as reported in Figure 5. The reason for the positive effect of oil demand shocks on domestic output might be due to higher world growth, which increases oil prices and also increases domestic output. Higher world growth may affect domestic growth through higher export demand.

Next, we perform the analyses on the net oil-exporting countries (not reported). For oil supply shocks, we observe positive and statistically significant output growth for Algeria, Iran, and Qatar. The effect for Libya is positive and for Bahrain it is negative, but they are not statistically significant. Lastly, we assess the effects of oil demand shocks on oil-exporting countries. The statistically significant effects are all positive, which may explain the evidence we had for Libya; it seems that not oil supply but oil demand shocks affect the output for Libya.

\section{SUMMARY AND CONCLUSIONS}

This study analyzes the effects of oil price shocks on 16 selected MENA economies: Algeria, Bahrain, Djibouti, Egypt, Iran, Iraq, Israel, Jordan, Kuwait, Libya, Morocco, Oman, Qatar, Syria, Tunisia, and the United Arab Emirates. The countries included in this study reflect an oil price-taking character, and the sample includes both net oil exporters and net oil importers.

The results of the tests indicate that one standard deviation shock in oil prices has a statistically significant and positive effect on the growth of the mostly net oil-exporting economies: Algeria, Iran, Iraq, Kuwait, Libya, Oman, Qatar, Syria, and the UAE. Oil price shocks do not appear to impose statistically significant effects on the economies of the other countries: Bahrain, Djibouti, Egypt, Israel, Jordan, Morocco and Tunisia. In order to elaborate on the estimates of the latter countries, following Uhlig (2005) and Lippi and Nobili (2008), we identify the oil shocks as oil demand and oil supply shocks. Overall estimates for the latter countries suggest that output decreases with positive oil supply shocks but output increases with positive oil demand shocks. When we repeat the exercise for oil-exporting countries, the output of these countries increases regardless of whether oil prices increases are associated with oil demand shocks or oil supply shocks. This suggests that understanding the nature of oil shocks (oil demand versus oil supply) is critical for policy makers - especially for the policy makers of 
oil-importing countries. Hunt (2005) argues that if policy makers misunderstand the effect of oil price shocks on output and labor and attempt to resist the required declines in their real wages, higher oil prices can result in significant disruptions to real activity.

This study limits itself to an analysis of the effects of oil price shocks on the growth of the economic activities of selected MENA countries. The results constitute a small portion of the domain of associations and further studies in relation to existing economic structures and the transmission channels of oil price movements are required. For example, the effects of oil price shocks on fiscal balance, current account, interest rates and real exchange rates could also be analyzed.

\section{REFERENCES}

Aleisa, E. A. and S. Dibooglu (2002). "Sources of Real Exchange Rate Movements in Saudi Arabia." Journal of Economics and Finance 26(1): 101-110.

Amano, R. and S.Van Norden (1995). "Oil Prices and the Rise and Fall of The U.S. Real Exchange Rate.” International Finance, EconWPA \# 9502001135/90.

Bernanke B. S., M. Gertler and M. Watson (1997). "Systematic Monetary Policy and the Effects of Oil Price Shocks." Brookings Papers on Economic Activity Vol. 1997, No. 1: 91-157.

Berument, H. and M. Pasaogullari (2003). "Effects of the Real Exchange Rate on Output and Inflation: Evidence From Turkey." Developing Economies 41(4): 401-435,

Berument, H. and H. Tasci (2002). "Inflationary Effect of Crude Oil Prices in Turkey." Physica A 316: 568-580.

Bjørnland, H. C. (2008). "Oil Price Shocks and Stock Market Booms in an Oil Exporting Country." Working Paper from Norges Bank \# 16.

Bohi, D. R. (1989). Energy Price Shocks and Macroeconomic Performance. Washington, D.C.: Resources for the Future.

Boskin, Michael J., Dulberger, Eller R., Gordon, Robert J., Griliches, Zvi, and Jorgenson, Dale (1996). "Toward a More Accurate Measure of the Cost of Living." Final Report to the Senate Finance Committee from the Advisory Commission to Study the Consumer Price Index, Washington: Senate Finance Committee, December 4.

Burbidge, J. and A. Harrison (1984). "Testing for The Effect of Oil Price Rises Using Vector Autoregressions." International Economic Review 25: 459-484.

Brown, S. P. A. and M. K. Yucel (2000). "Oil Prices and the Economy." Soutwest Economy, Federal Reserve Bank of Dallas, Issue: 4.

Bryan M. F. and S. G. Cecchetti (1993). "The Consumer Price Index as a Measure of Inflation." Economic Review, Federal Reserve Bank of Cleveland, Issue Q IV: 15-24.

Chen, H. and C. Chen (2007). "Oil Prices and Real Exchange Rate." Energy Economics, 29: 390404.

Canova, F. and G. De Nicolo (2002). "Monetary Disturbances Matter for Business Cycle Fluctuations in The G-7." Journal of Monetary Economics 49: 1131-1159.

Corden, W. (1984). "Booming Sector and Dutch Disease Economics: Survey and Consolidation." Oxford Economic Paper 36: 359-80.

Cuñado, J. and F. Pérez de Gracia (2003). "Do Oil Price Shocks Matter? Evidence for some European countries." Energy Economics 25: 137-154.

Cushman, D. O. and T. Zha (1997). "Identifying Monetary Policy in a Small Open Economy under Flexible Exchange Rates.” Journal of Monetary Economics 39: 433-448.

Darby, M. R. (1982). "The Price of Oil and World Inflation and Recession." American Economic Review 72: 738-751. 


\section{4 / The Energy Journal}

De Grauwe, Paul (1996). International Money: Postwar-Trends and Theories. Oxford: Oxford University Press.

Dedola, L. and S. Neri (2006). "What Does a Technology Shock Do? A VAR Analysis with ModelBased Sign Restrictions." European Central Bank Working Paper Series, No:705.

Enders, W. (1995). Applied Econometric Time Series. John Wiley \& Sons Inc. New York.

Gisser, M. and T. H. Goodwin (1986). "Crude Oil and the Macroeconomy: Tests of Some Popular Notions." Journal of Money, Credit and Banking 18: 95-103.

Gordon, R.J. and T. vanGoethem (2005). "A Century of Housing Shelter Prices: Is There a Downward Bias in the CPI?" NBER Working Papers \# 11776.

Golub, Stephen (1983). "Oil Prices and Exchange Rates." Economic Journal 93: 576-93.

Hamilton, J. D. (1983). "Oil and the Macroeconomy since World War II." Journal of Political Economy 91: 228-248.

Hamilton, J. D. (1996). "This Is What Happened to the Oil Price-Macroeconomy Relationship." Journal of Monetary Economics 38: 215-220.

Hooker, Mark A. (1996). "What Happened to the Oil Price-Macroeconomy Relationship?" Journal of Monetary Economics 38: 195-213.

Hunt, B. (2005). "Oil Price Shocks: Can They Account for the Stagflation in the 1970s?" IMF Working Paper \# 05/215.

Husain, T. and Ter-Martirosyan (2008). "Fiscal Policy and Economic Cycles in Oil-Exporting Countries." IMF working Paper \# WP/08/253.

Jiménez-Rodríguez, R. (2008). "The Impact of Oil Price Shocks: Evidence from the Industries of Six OECD Countries." Energy Economics 30(6): 3095-3108.

Jiménez-Rodríguez, R. and M. Sánchez (2005). "Oil Price Shocks and Real GDP Growth: Empirical Evidence for Some OECD Countries." Applied Economics 37: 201-228.

Kamin, S. B. and J. H. Rogers (2000). "Output and the Real Exchange Rate in Developing Countries: An Application to Mexico". Journal of Development Economics 61: 85-109.

Kornonen, L. and T. Juurikkala (2007). "Equilibrium Exchange Rates In Oil-Dependent Countries." BOFIT Discussion Papers 8.

Lee, K., S. Ni, and R. A. Ratti (1995). "Oil Shocks and the Macroeconomy: The Role of Price Variability." Energy Journal 16: 39-56.

Levin, A. T. and P. N. Loungani (1996). "Oil, Money, and Economic Activity in the G-7 Countries: Implications of the FRB/MCM". Paper presented at the DOE Conference, International Energy Security: Economic Vulnerability to Oil Price Shocks. October ,Washington D.C.

Lippi, F. and A. Nobili (2008). "Oil and the Macroeconomy: A Structural VAR Analysis with Sign Restrictions." Center for Economic Policy Research, Working Paper \# 6830.

Maeso-Fernandez F, C. Osbat, B. Schnatz (2002). "Determinants of the Euro Real Effective Exchange Rate: A BEER/PEER Approach.” Australian Economic Papers 41(4): 437-461.

Miguel C. de, B. Manzano, and J. M. Martin-Moreno (2003). "Oil Price Shocks and Aggregate Fluctuations." The Energy Journal 24(2): 47-61.

Mork, K. A. (1989). "Oil and the Macroeconomy When Prices Go Up and Down: An Extension of Hamilton's Results." Journal of Political Economy 91: 740-744.

Mork, K, O. Olsen, and H. Mysen (1994). "Macroeconomic Responses to Oil Price Increases and Decreases in Seven OECD Countries." The Energy Journal 15: 19-35.

Mountford A. (2005). "Leaning Into the Wind: A Structural VAR Investigation of UK Monetary Policy." Oxford Bulletin of Economics and Statistics 67(5): 597-621.

Nordhaus, W.D. (1980). "Oil and Economic Performance in Industrial Countries." Brooking Papers on Economic Activity 2: 341-388.

Okun A.M. (1975). "A Postmortem of the 1974 Recession." Brooking Papers on Economic Activity 1: 207-221.

Papapetrou, E. (2001). "Oil Price Shocks, Stock Market, Economic Activity and Employment in Greece.” Energy Economics 23: 511-532.

Perry, G.L. (1977). "Potential Output and Productivity." Brooking Papers on Economic Activity 1: $11-47$. 
Rasche, R. H. and J. A. Tatom (1977). "The Effects of the New Energy Regime on Economic Capacity, Production and Prices." Federal Reserve Bank of St. Louis Review 59(4): 2-12.

Rasche, R. H. and J. A. Tatom (1981). "Energy Price Shocks, Aggregate Supply and Monetary Policy: The Theory and International Evidence." Carnegie-Rochester Conference Series on Public Policy 14: $125-142$.

Santini, D. J. (1985). "The Energy-Squeeze Model: Energy Price Dynamics in U.S. Business Cycles.” International Journal of Energy Systems 5: 18-25.

Uhlig, H. (2005). "What are the Effects of Monetary Policy on Output? Results from an Agnostic Identification Procedure." Journal of Monetary Economics 52: 381-419.

World Fact Book (2007). Available at http://www.flagstore.com/facts/ba.html.

Zha, T. (1999). "Block Recursion and Structural Vector Autoregressions." Journal of Econometrics 90, 291-316.

\section{APPENDIX. UNIT ROOT TESTS}

Table A1 reports the unit root tests for the logarithm of the real GDP series for each country and real oil prices. Panel A reports three unit root tests in levels of series with the constant term. Note that the null is the presence of a unit root for both of these tests: Augmented Dickey-Fuller and Phillips and Perron Tests; rejecting the null indicates the presence of stationary. On the other hand, the null hypothesis is the presence of stationary for the Kwiatowski, Phillips, Schmidt, and Shin tests; rejecting the null indicates the presence of unit roots. Panel B repeats the exercise with the constant term and time trend. Panel $\mathrm{C}$ performs the test on the series' first difference with the constant term. Overall, it can be suggested that the series are difference stationary, except for Djibouti.

Panel D reports the Engle and Granger cointegration tests between the logarithm of each country's GDP and real oil prices. Overall, we could not detect the presence of cointegration in each pair of variables at the $5 \%$ level, except for Jordan. 


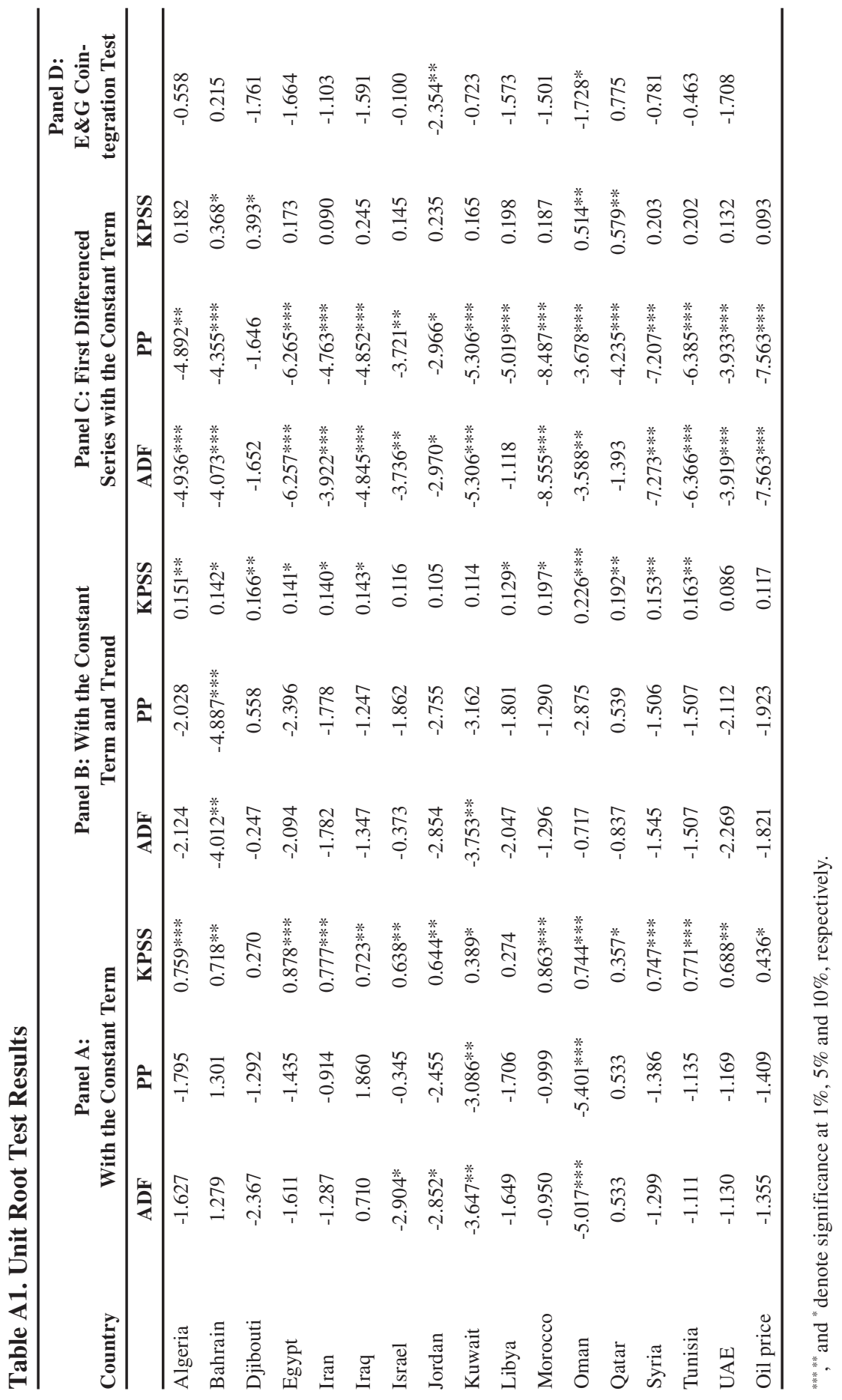

